\title{
Interaction between Biological Activities on Rice Seedlings of Dehydroabietic Acid Derivatives and Gibberellin $\mathrm{A}_{3}^{+}$
}

\author{
Shiro OKuda, Shigeru SanaI, Yasuo Kimura,* \\ Saburo TAMURA* and the late Akira TAHARA** \\ Research Department, Kaken Chemical Co., Ltd., Bunkyo-ku, Tokyo; \\ *Department of Agricultural Chemistry, The University of Tokyo, Bunkyo-ku, Tokyo; \\ **The Institute of Physical and Chemical Research, Wako-shi, Saitama-ken
}

Received January 12, 1976

Effects of hydrofluorene and hydrophenanthrene compounds derived from dehydroabietic acid on the second leaf sheath growth of rice seedlings were examined in the presence and absence of gibberellin $\mathrm{A}_{3}\left(\mathrm{GA}_{3}\right)$. In the absence of $\mathrm{GA}_{8}$, nineteen compounds at $100 \mathrm{ppm}$ inhibited more than $20 \%$ the growth of normal rice seedlings. In the presence of $\mathrm{GA}_{3}$ $(1.5 \mathrm{ppm})$ with dwarf rice seedlings, nine compounds at $500 \mathrm{ppm}$ suppressed the elongation caused by the hormone, and a compound was slightly promotive. Then, three compounds were selected and subjected to the bioassay under various conditions.

Considering a structural similarity to gibberellins, we have examined by use of various plants biological activities of compounds belonging to hydrofluorene and hydrophenanthrene series, which were prepared by one of us (the late A. Tahara) ${ }^{1 \sim 30}$ starting with $l$ abietic acid. In this paper we wish to report the effects of 114 compounds on the second leaf sheath growth of normal and dwarf rice seedlings in the absence and presence of gibberellin $\mathrm{A}_{3}\left(\mathrm{GA}_{3}\right)$. The numbering given for the ring structures of the hydrofluorene and hydrophenanthrene derivatives tested here is as follows:

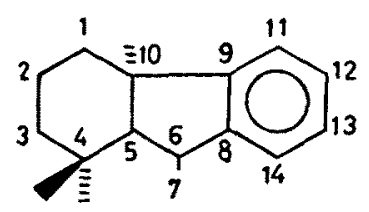

Hydrofluorenes

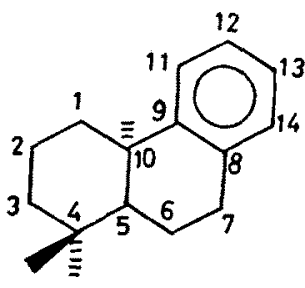

Hydrophenanthrenes

\section{MATERIALS AND METHODS}

1. Compounds tested. All of the compounds tested here are classified according to their fundamental structures and are listed in Table I together with their

+ Studies on Biological Activities of Dehydroabietic Acid Derivatives on Plants. Part I. physical constants.

2. Plants for bioassay. Varieties of rice plants (Oryza sativa $\mathrm{L}$.) used here for the bioassay were as follows: normal, Kinmaze; dwarf, Tanginbozu.

3. Procedure of bioassay. Rice seeds just after germination were transferred into a test tube $(6 \times 2.5$ i.d.cm), to which $1 \mathrm{ml}$ of Hoagland's solution containing a definite amount of a test sample with or without $\mathrm{GA}_{3}(1.5 \mu \mathrm{g})$ had been added. The test tube was covered with polyethylene film and kept under a light source of $c a, 3000$ lux at $30^{\circ} \mathrm{C}$. After a week, the length of each second leaf sheath was measured. The effect of the compound was expressed as the percentage of the control without the sample (control $=100$ ).

\section{RESULTS AND DISCUSSION}

Effects of the compounds at $100 \mathrm{ppm}$ on the second leaf sheath growth of normal rice seedlings are shown in Table II. Among the hydrofluorene compounds, Nos. 11, 16 and 26 each possessing the 4,6-diacid structure showed inhibition more than $20 \%$. Only a compound (No. 25) was slightly promotive in the hydrofluorene series.

On the other hand, there were 17 compounds (Nos. 45, 46, 50, 58, 81, 86, $91 \sim 101$ ) which showed more than $20 \%$ inhibition among the hydrophenanthrene derivatives. The common structural characteristics ob- 
Table I. Dehydroabietic Acid Derivatives Tested in the Experiment

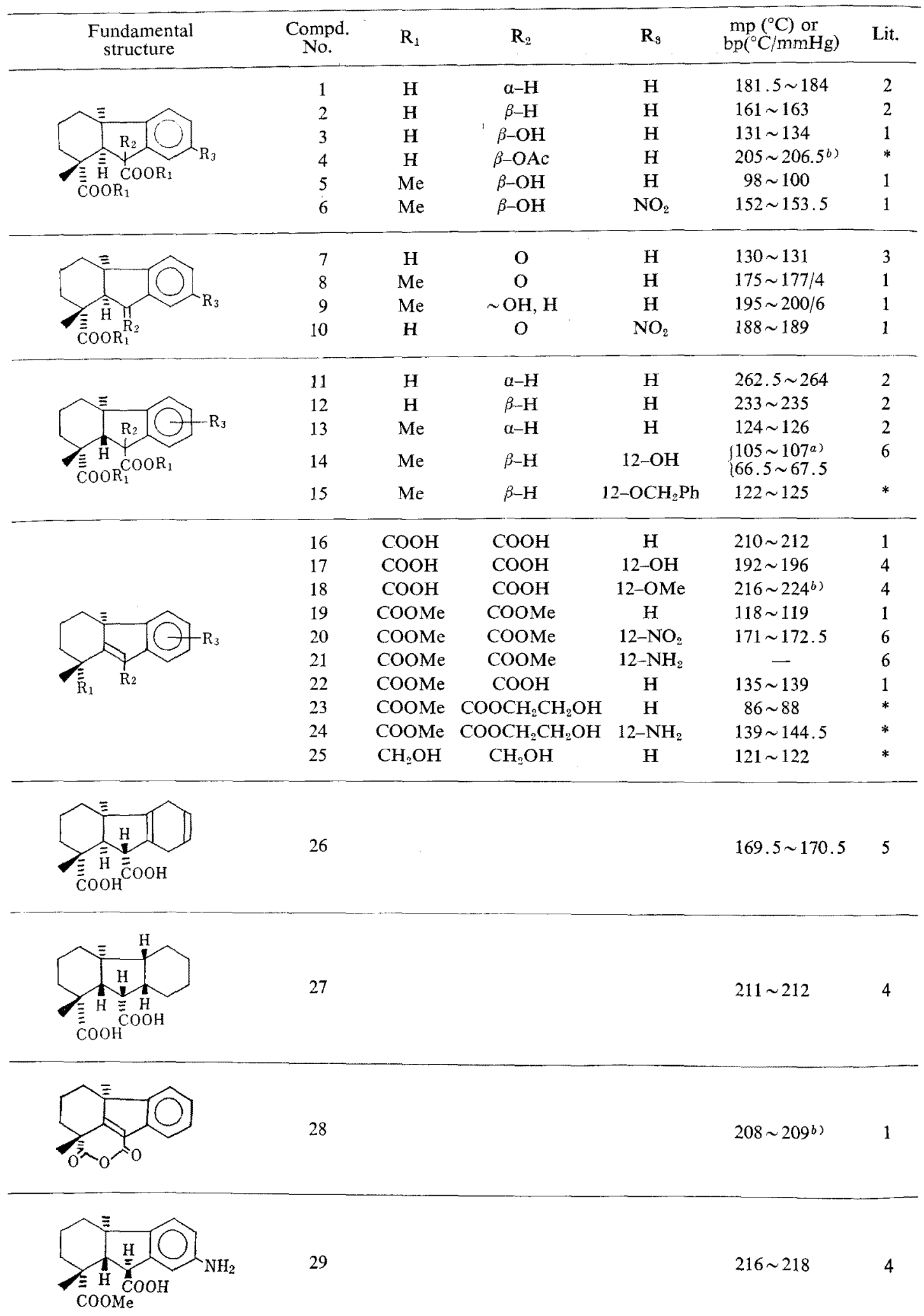


TABLE I. (cont.)

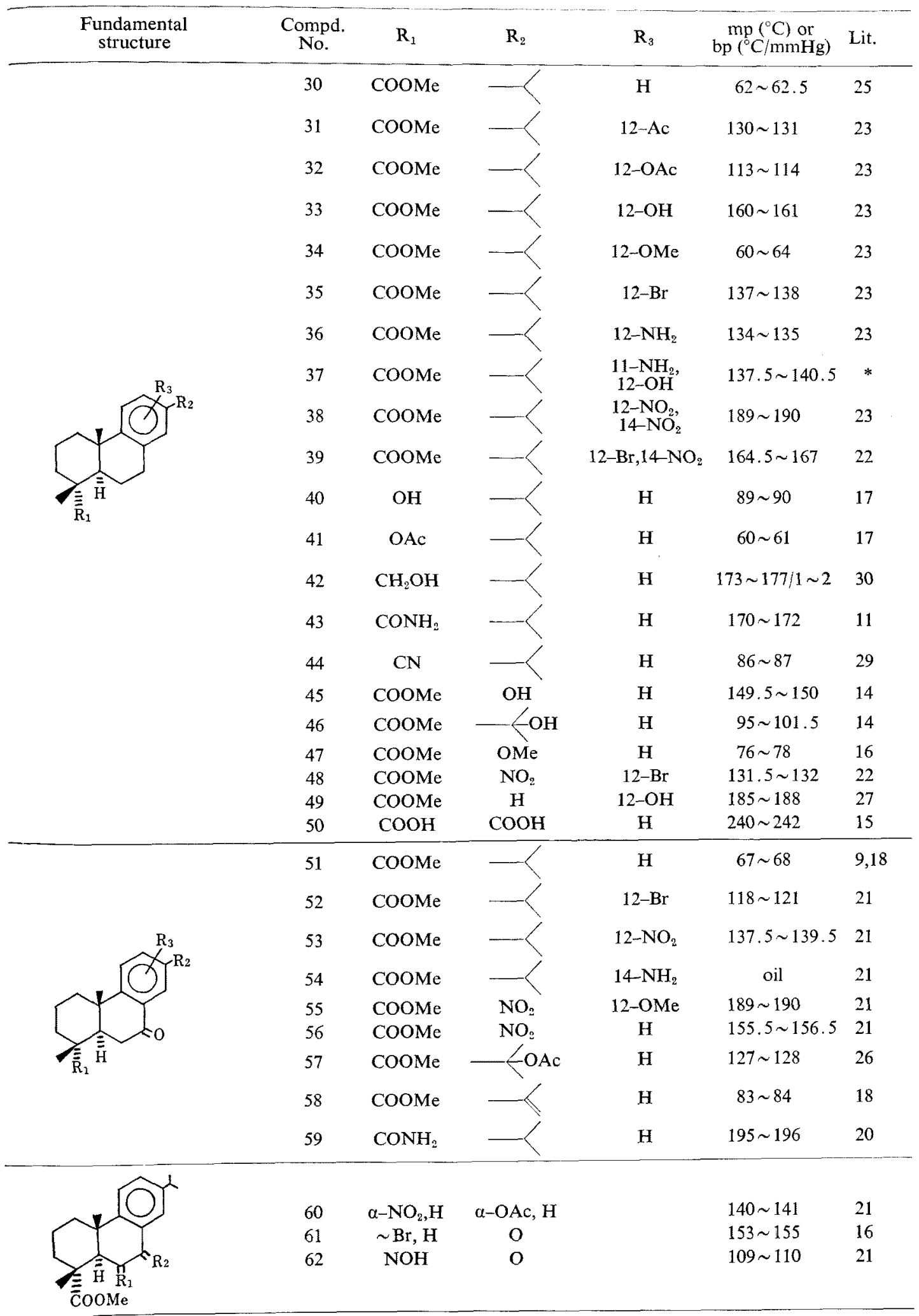


TABLE I. (cont.)

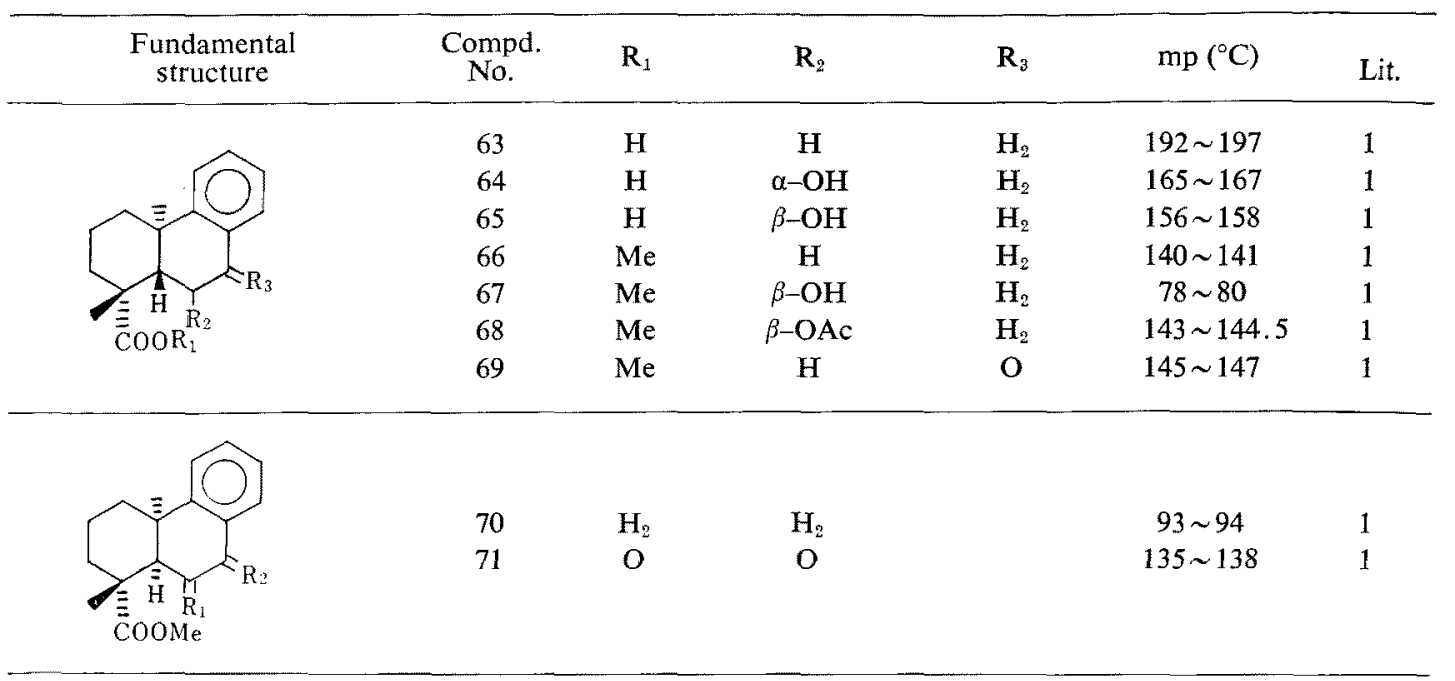

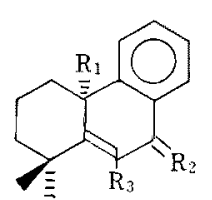

COOMe

$\begin{array}{rccclr}72 & \mathrm{Me} & \mathrm{O} & \mathrm{H} & 144 \sim 146 & 10 \\ 73 & \mathrm{Me} & \mathrm{O} & \mathrm{OAc} & 115 \sim 117 & 1 \\ 74 & \mathrm{Me} & \mathrm{H}_{2} & \mathrm{H} & 121 & 1 \\ 75 & \mathrm{CH}_{2} \mathrm{OAc} & \mathrm{O} & \mathrm{H} & 148.5 \sim 150.5 & 10\end{array}$

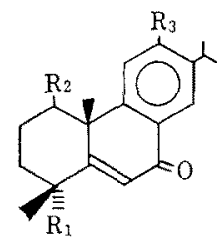

$\begin{array}{ccc}76 & \text { COOMe } & \mathrm{H} \\ 77 & \text { COOMe } & \mathrm{H} \\ 78 & \text { COOMe } & \alpha-\mathrm{Br} \\ 79 & \text { COOMe } & \beta-\mathrm{Ac} \\ 80 & \mathrm{CH}_{2} \mathrm{OAc} & \mathrm{H}\end{array}$

$\mathrm{H}$

oil $(154 \sim 155)^{03} \quad 16$

$\mathrm{NO}_{2} \quad 128 \sim 130$

H $124 \sim 125 \quad 24$

$80-\mathrm{CH}_{2} \mathrm{OAc}$

$\mathrm{H}$

$\mathrm{H}$
$\mathrm{H}$

$141 \sim 142$

oil

12

25

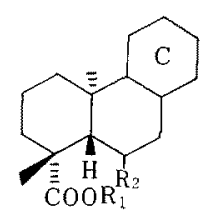

\section{1}

82

83

84

85

86

$\mathrm{H}$
$\mathrm{H}$
$\mathrm{H}$
$\mathrm{Me}$
$\mathrm{Me}$
$\mathrm{Me}$

$\mathrm{H}$
$\beta-\mathrm{OH}$
$\beta-\mathrm{OH}$
$\mathrm{H}$
$\alpha-\mathrm{OH}$
$\beta-\mathrm{OH}$

C-ring

8,9-4

$$
8,9-4
$$

$8 \beta, 9 \beta-\mathrm{H}$

$8 \alpha, 9 \beta-H$

$8 \alpha, 9 \beta-\mathrm{H}$

$8 \beta, 9 \beta-\mathrm{H}$

$\begin{array}{cc}143 \sim 146 & 1 \\ \text { oil } & 1 \\ 149.5 \sim 151 & 1 \\ 59 \sim 61 & 1 \\ 142.5 \sim 144.5 & 1 \\ 84 \sim 85 & 1\end{array}$<smiles>C[C@@H]1[C@@H]2CC3CCCCC3[C@@]3(C)CCC[C@@]1(C)[C@H]3C(=O)O2</smiles>

1
1
0


TABle I. (cont.)

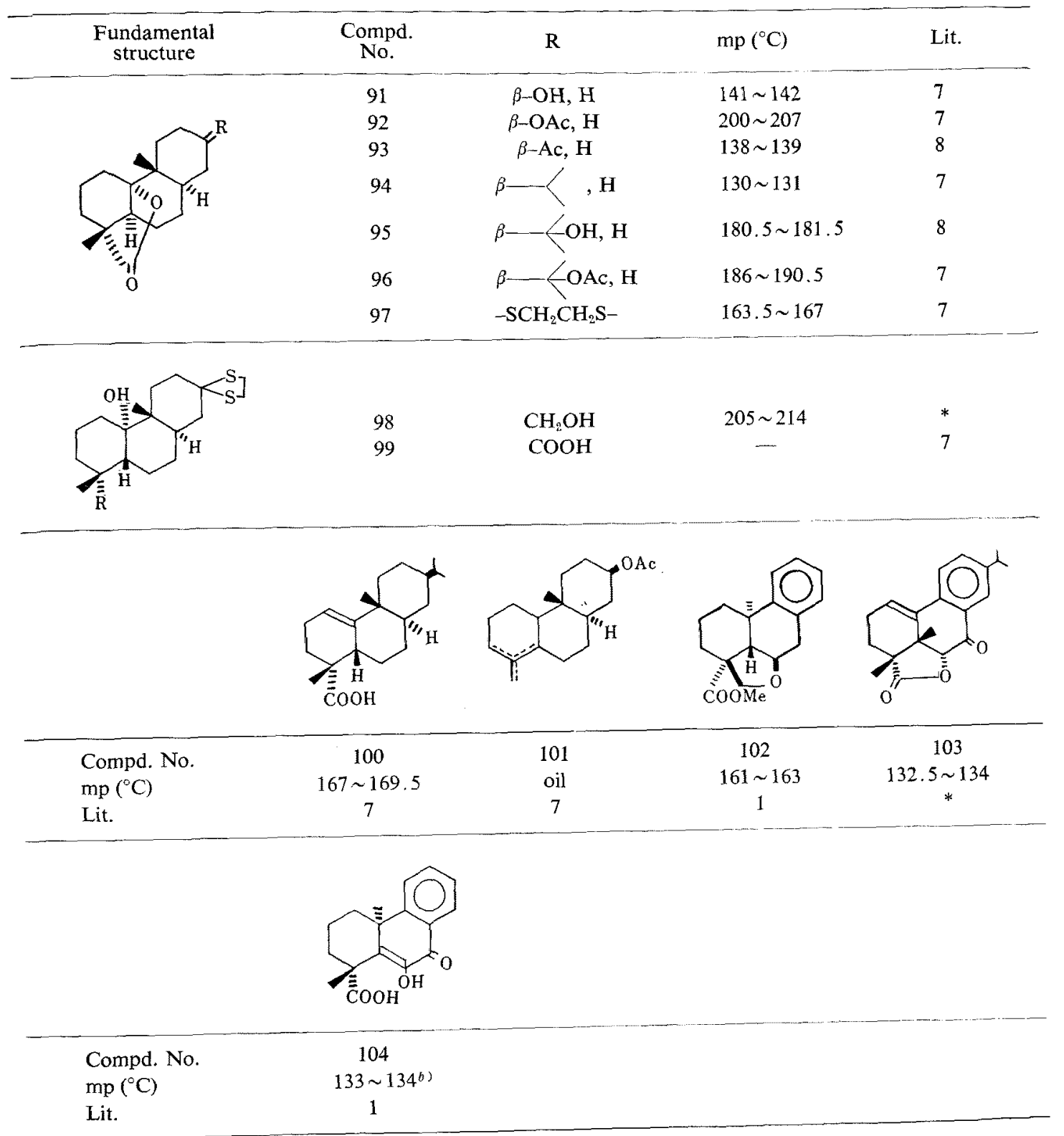

$\begin{aligned} & \mathrm{Compd} . \mathrm{No} . \\ & \mathrm{mp}\left({ }^{\circ} \mathrm{C}\right) \text { or } \\ & \mathrm{bp}\left({ }^{\circ} \mathrm{C} / \mathrm{mmHg}\right) \\ & \mathrm{Lit} .\end{aligned}$
$139 \sim 141.5$


TABLE I. (cont.)

(n)

Table II. Effect of Some Dehydroabietic Acid Derivatives on the Second Leaf Sheath Growth of Rice Seedlings (normal cv., Kinmaze)

\begin{tabular}{cccccccc}
\hline $\begin{array}{c}\text { Compd. } \\
\text { No. }\end{array}$ & $\begin{array}{c}\text { Relative } \\
\text { activity }\end{array}$ & $\begin{array}{c}\text { Compd. } \\
\text { No. }\end{array}$ & $\begin{array}{c}\text { Relative } \\
\text { activity }\end{array}$ & $\begin{array}{c}\text { Compd. } \\
\text { No. }\end{array}$ & $\begin{array}{c}\text { Relative } \\
\text { activity }\end{array}$ & $\begin{array}{c}\text { Compd. } \\
\text { No. }\end{array}$ & $\begin{array}{c}\text { Relative } \\
\text { activity }\end{array}$ \\
\hline 1 & $88^{(a)}$ & 27 & 91 & 69 & 100 & 91 & 75 \\
2 & 89 & 29 & 88 & 70 & 105 & 92 & 60 \\
3 & 98 & 40 & 93 & 71 & 96 & 93 & 66 \\
4 & 94 & 41 & 98 & 72 & 97 & 94 & 66 \\
7 & 96 & 42 & 83 & 73 & 90 & 95 & 59 \\
8 & 89 & 43 & 101 & 74 & 82 & 96 & 73 \\
9 & 99 & 45 & 74 & 75 & 85 & 97 & 59 \\
11 & 73 & 46 & 70 & 76 & 104 & 98 & 63 \\
12 & 84 & 49 & 81 & 81 & 59 & 99 & 62 \\
16 & 78 & 50 & 70 & 82 & 94 & 100 & 70 \\
17 & 98 & 51 & 92 & 83 & 89 & 101 & 75 \\
18 & 96 & 58 & 70 & 84 & 97 & 102 & 84 \\
21 & 101 & 63 & 98 & 85 & 107 & 104 & 88 \\
22 & 98 & 64 & 91 & 86 & 44 & 106 & 89 \\
23 & 105 & 65 & 83 & 87 & 91 & 107 & 95 \\
24 & 95 & 66 & 98 & 88 & 88 & 108 & 97 \\
25 & 111 & 67 & 89 & 89 & 85 & 109 & 98 \\
26 & 77 & 68 & 89 & 90 & 83 & & \\
\hline
\end{tabular}

a) The relative activity is expressed as the percentage of the control (100; second leaf sheath length $25.4 \mathrm{~mm}$ ). Concentration of sample: $100 \mathrm{ppm}$. 
Table III. Effect of Dehydroabietic Acid Derivatives on the Second Leaf Sheath Growth or Rice Seedlings (dwarf cy., Tanginbozu)

\begin{tabular}{rrrrrrrr}
\hline $\begin{array}{c}\text { Compd. } \\
\text { No. }\end{array}$ & $\begin{array}{c}\text { Relative } \\
\text { activity }\end{array}$ & $\begin{array}{c}\text { Compd. } \\
\text { No. }\end{array}$ & $\begin{array}{c}\text { Relative } \\
\text { activity }\end{array}$ & $\begin{array}{c}\text { Compd. } \\
\text { No. }\end{array}$ & $\begin{array}{c}\text { Relative } \\
\text { activity }\end{array}$ & $\begin{array}{c}\text { Compd. } \\
\text { No. }\end{array}$ & $\begin{array}{c}\text { Relative } \\
\text { activity }\end{array}$ \\
\hline 3 & $103^{a}>$ & 28 & 105 & 48 & 127 & 76 & 96 \\
5 & 97 & 30 & 99 & 50 & 61 & 77 & 100 \\
6 & 101 & 31 & 111 & 51 & 102 & 78 & 119 \\
7 & 0 & 32 & 114 & 52 & 99 & 79 & 77 \\
10 & 62 & 33 & 101 & 53 & 117 & 80 & 104 \\
12 & 93 & 34 & 91 & 54 & 96 & 94 & 99 \\
13 & 112 & 35 & 97 & 55 & 98 & 103 & 76 \\
14 & 91 & 36 & 79 & 56 & 96 & 105 & 85 \\
15 & 103 & 37 & 98 & 57 & 96 & 110 & 104 \\
16 & 104 & 38 & 117 & 59 & 79 & 111 & 72 \\
19 & 99 & 39 & 101 & 60 & 100 & 112 & 97 \\
20 & 101 & 42 & 97 & 61 & 100 & 113 & 96 \\
22 & 80 & 44 & 97 & 62 & 93 & 114 & 96 \\
24 & 96 & 47 & 97 & 71 & 35 & & \\
\hline
\end{tabular}

a) The second leaf sheath length of the control (GA without the sample) was $75.0 \mathrm{~mm}$. Sample (500 ppm) $+\mathrm{GA}_{3}(1.5 \mathrm{ppm})$.

served in these compounds are as follows:

1) The presence of a $\beta$-methyl at $\mathrm{C}-10$ and a carboxyl or methoxycarbonyl at C-4 (Nos. 45, 46, 50 and 58).

2) The presence of a lactone ring between C -4 and C -10 position (Nos. $91 \sim 97$ ).

3) The presence of a methyl group at $\mathrm{C}-9$ (Nos. 91 101).

4) The presence of an $\alpha$-hydroxyl at $\mathrm{C}$ 10 (No. 98 and 99 ).

In the next experiment carried out in the presence of $\mathrm{GA}_{3}$ (1.5 ppm) using dwarf rice seedlings, two oxo-acids (No. 7 and 10) of the hydrofluorene series as well as two compounds (No. 50 and 71) of the hydrophenanthrene series showed a remarkable inhibition: No. $7,100 \%$ inhibition; No. $10,38 \%$; No. 50 , $39 \%$; No. $71,65 \%$. Besides, compound No. 22 belonging to the hydrofluorene series and compounds Nos. 36, 59, 79, 103 and 111 belonging to the hydrophenanthrene series showed suppression more than $20 \%$.

There were 7 compounds (Nos. 13, 31, 32, $38,48,53$ and 79) which showed a synergistic effect with $\mathrm{GA}_{3}$, and No. 48 caused elongation more than $20 \%$. However, no definite relationship was observed between the structure and the promotive effect of these compounds.
Based on the noticeable effects in the first and second experiments, compounds Nos. 7, 10 and 71 were selected and tested at various concentrations in the presence and absence of $\mathrm{GA}_{3}$ by use of dwarf rice seedlings.

As shown in Table IV, in the presence of $\mathrm{GA}_{3}$, every compound suppressed the elongation caused by the hormone: No. 7 seemed the most active. On the other hand, in the absence of $\mathrm{GA}_{3}$, they were all inactive.

When the three compounds were applied to normal rice seedlings in the presence of $\mathrm{GA}_{3}$, Nos. 7 and 10 showed suppresion as in the

TABLE IV. EFFECT OF Compounds Nos. 7, 10 and 71 on the Second Leaf Sheath Growth of Rice Seedlings (dwarf cv., Tanginbozu)

\begin{tabular}{|c|c|c|c|c|c|}
\hline \multirow{2}{*}{$\begin{array}{c}\text { Compd. } \\
\text { No. }\end{array}$} & \multicolumn{5}{|c|}{ Relative activities } \\
\hline & $500 \mathrm{ppm}$ & $300 \mathrm{ppm}$ & $200 \mathrm{ppm}$ & $100 \mathrm{ppm}$ & 30 ppm \\
\hline $7^{a 3}$ & 17 & & 74 & 86 & 86 \\
\hline $7^{b)}$ & & 94 & & 101 & \\
\hline $10^{a\rangle}$ & 36 & & 52 & 70 & 74 \\
\hline $10^{b)}$ & & 99 & & 97 & \\
\hline $71^{03}$ & 41 & & 57 & 69 & 73 \\
\hline $71^{b)}$ & & 97 & & 93 & 103 \\
\hline
\end{tabular}

a) In the presence of $\mathrm{GA}_{3}(1.5 \mathrm{ppm})$. The second leaf sheath length of the control was $74.6 \mathrm{~mm}$.

b) In the absence of $\mathrm{GA}_{3}$, the length of the control was $15.5 \mathrm{~mm}$. 
Table V. Effect of Compounds Nos. 7, 10 ANd 71 ON the Second Leaf Sheath Growth of Rice SeEdlings (normal cv., Kinmaze)

\begin{tabular}{rcccc}
\hline \multicolumn{5}{c}{ Relative activities } \\
Compd. & \multicolumn{5}{c}{$\begin{array}{c}\text { No } \\
\text { No. }\end{array}$} & $500 \mathrm{ppm}$ & $200 \mathrm{ppm}$ & $100 \mathrm{ppm}$ & $30 \mathrm{ppm}$ \\
\hline 7 & 0 & 15 & 93 & 98 \\
10 & 42 & 72 & 101 & 103 \\
71 & 103 & 103 & & 101 \\
\hline
\end{tabular}

The second leaf sheath length of the control was $31.8 \mathrm{~mm}$.

case of dwarf rice seedlings (Table V). However, No. 71 was inactive at $500 \mathrm{ppm}$.

Some of the growth retardants have been shown to suppress plant growth due to the inhibition of biosynthesis of gibberellins. ${ }^{31,32)}$ The actions of Nos. 7 and 10 observed in this experiment were quite similar to that of AMO1618 on the growth of bean hypocotyls in the presence and absence of $\mathrm{GA}_{3} \cdot{ }^{33}$ Accordingly, it would be conceivable that Nos. 7 and 10 inhibit the gibberellin biosynthesis in the seedling of normal rice.

On the other hand, No. 71 does not seem to interfere with the gibberellin biosynthesis in normal rice plants, but it disturbs, in some way, the action of $\mathrm{GA}_{3}$ exogeniously applied.

The modes of actions of these compounds should be examined in the future.

\section{REFERENCES}

1) A. Tahara, Abstract of Papers, the 90th. Annual Meeting of the Pharmaceutical Society of Japan at Osaka, April 1972, p. 1.

2) A. Tahara and Y. Ohtsuka, J. Chem. Soc. (Perkin I), 1972, 320 .

3) M. Ohta, Chem. Pharm. Bull.(Japan), 5, 256(1957).

4) A. Tahara, T. Nakata, Y. Ohtsuka, S. Takada and Y. Tanabe, Yakugaku Zasshi, 93, 957 (1973).

5) A. Tahara and Y. Ohtsuka, Chem. Pharm. Bull. (Tokyo), 20, 1648 (1972).
6) A. Tahara and Y. Ohtsuka, Chem. Pharm. Bull., 20, 1637 (1972).

7) A. Tahara and Y. Harigaya and M. Onda, ibid., 20, 459 (1972).

8) J. Minn, T. F. Sanderson and L. A. Subluskey, $J$. Amer. Chem. Soc., 78, 630 (1956).

9) E. Wenkert and B.G. Jackson, ibid., 80, 211 (1958).

10) T. Ohsawa, M. Kawahara and A. Tahara, Chem. Pharm. Bull. (Tokyo), 21, 487 (1973).

11) H. Kanno, Nippon Kagaku Zasshi, 82, 113 (1961).

12) A. Tahara, H. Mizuno and T. Ohsawa, Chemistry Letters, 1972, 1163.

13) A. Tahara and T. Ohsawa, Chem. Pharm. Bull. (Tokyo), 21, 483 (1973).

14) A. W. Burgsthaler and L. R. Worden, J. Amer. Chem. Soc., 86, 96 (1964).

15) M. Ohta, Chem. Pharm. Bull. (Japan), 4, 273 (1956).

16) E. Wenkert, R. W. J. Carney and C. Kaneko, J. Amer. Chem. Soc., 83, 4440 (1961).

17) C. R. Bennett, R. C. Cambie, R. A. Franich and T. J. Fullerton, Aust. J. Chem., 22, 1711 (1969).

18) P.F. Richie, T.F. Sanderson and L.F. McBurney, J. Amer. Chem. Soc., 76, 723 (1954).

19) Y. Ohtsuka and A. Tahara, Chem. Pharm. Bull. (Tokyo), 21, 643 (1973).

20) Y. Ohtsuka and A. Tahara, ibid., 21, 653 (1973).

21) A. Tahara, H. Akita and Y. Ohtsuka, ibid., 22, 1547 (1974)

22) A. Tahara, H. Akita and Y. Ohtsuka, ibid., 22, 1555 (1974).

23) R. C. Cambie and R. A. Franich, Chem. Comm., 1970, 845 .

24) A. Tahara and H. Mizuno, Tetrahedron Letters, 1974, 523.

25) L. F. Fieser, J. Amer. Chem. Soc., 60, 159 (1938).

26) T. F. Sanderson, U. S. Pat., 2750368(1956)[C.A. 51, 1278f (1957)].

27) A. Tahara and H. Akita, Chem. Pharm. Bull. (Tokyo), 23, 1976 (1975).

28) Y. Ohtsuka and A. Tahara, ibid, 21, 643 (1973).

29) J. A. Barltrop, A. C. Day and D. B. Bigley, J. Chem. Soc., 3185 (1961).

30) H. Kanno, Tokyo Gakugei Daigaku Kenkyu Hokoku, 4 bu, Shizenkagaku, 12, 37 (1961).

31) H. M. Cathey, Ann. Rev. Plant Physyol., 15, 271 (1965).

32) A. Lang, Ann. Rey. Plant Physiol., 21, 537 (1970).

33) R. J. Downs and H. M. Cathey, Bot. Gaz., 121, 233 (1960). 